\title{
The biological characteristics and distribution of the greenbug, Schizaphis graminum, and Russian wheat aphid, Diuraphis noxia (Hemiptera: Aphididae), in Argentina and Chile
}

\author{
Ariel CluA ${ }^{1}$, Ana M. CASTRO ${ }^{1 *}$, Silvia RAMOS ${ }^{1}$, Daniel O. GIMENEZ ${ }^{1}$, Araceli VASiCEK ${ }^{1}$, \\ Hugo O. CHIDICHIMO ${ }^{2}$ and ANTHONY F.G. DIXON ${ }^{3}$
}

\author{
${ }^{1}$ Department of Natural Sciences, Facultad de Ciencias Agrarias y Forestales, UNLP. CC 31 (1900) La Plata, Argentina; \\ e-mail: amcastro@isis.unlp.edu.ar. \\ ${ }^{2}$ Department of Plant Production, Facultad de Ciencias Agrarias y Forestales, UNLP. CC 31 (1900) La Plata, Argentina \\ ${ }^{3}$ School of Biological Sciences. University of East Anglia, Norwich, NR4, 7TY, U.K.
}

Key words. Greenbug, Schizaphis graminum, RWA, Diuraphis noxia, geographical distribution, reproductive behaviour, host-preference, biotypes

\begin{abstract}
The aphids Schizaphis graminum (Rondani) (greenbug) and Diuraphis noxia (Mordvilko) (Russian wheat aphid, RWA) were collected from several localities in Argentina and Southern Chile. Clones were established from aphids collected at each location. The host preferences were studied in free choice tests. Biotypes were characterized on the basis of aphid antibiosis and host plant tolerance. The production of sexuals was assessed under natural conditions, from March to November in 1997-2001, at La Plata $\left(34^{\circ} 55^{\prime} \mathrm{S}, 57^{\circ} 57^{\prime} \mathrm{W}\right)$. The greenbug distribution ranged from $24^{\circ} 40^{\prime}$ to $43^{\circ} 28^{\prime} \mathrm{S}$, and was bounded between isothermals $18-20^{\circ} \mathrm{C}$ and $8-10^{\circ} \mathrm{C}$, and isohyets $400-600 \mathrm{~mm}$ and greater than $1200 \mathrm{~mm}$. The aphids at all localities were collected from a wide range of cultivated and wild hosts. The biotypes in ten out of thirty-four populations were identified. One population was obligatorily parthenogenetic, the remainder cyclically parthenogenetic. No correlation was found between the region they came from and the period required for the induction of sexuals. RWA was found between $26^{\circ} 50^{\prime}$ and $43^{\circ} 28^{\prime} \mathrm{S}$, bounded by the isothermals $20-22^{\circ} \mathrm{C}$ and $8-10^{\circ} \mathrm{C}$, and isohyets $400-600 \mathrm{~mm}$ and $2000 \mathrm{~mm}$. In Chile, this aphid was only found in Osorno County, which lies on isothermal $8-10^{\circ} \mathrm{C}$ and is bounded by the isohyets $1000 \mathrm{~mm}$ and $2000 \mathrm{~mm}$. Only a few RWA genotypes (clones) produced sexuals irrespective of the host they were collected from, period of the year, region, current host, or the day length and average temperature of the rearing conditions. For the first time, RWA was found infesting cultivated as well as wild oats in South America. At low latitudes, populations of both aphid species were found only infesting wild Sorghum halepensis (L).
\end{abstract}

\section{INTRODUCTION}

The greenbug, Schizaphis graminum (Rondani) and the Russian wheat aphid, RWA, Diuraphis noxia (Mordvilko) are the two economically most important insect pests of wheat and barley throughout much of the Americas. The greenbug is well adapted to conditions in the Americas, whilst the RWA is the last of several recent aphid introductions into Argentina and Chile. Russian wheat aphid was first discovered in Texas, USA, in 1986, and is now widespread in the USA and Canada (Kindler \& Springer, 1989; Peairs et al., 1989). This species was first found in Chile in 1988 and in Argentina in 1992 (Ortego \& Delfino, 1994). It was found in the main cereal producing region of Argentina, south of Buenos Aires province, in 1994 (Bellone \& Almaraz, 1995), and then spread northwards and eastwards infesting barley and wheat (Triticum aestivum and T. durum) in 1995 (Castro et al., 2000, 2001). Parasitoids and chemicals failed to control this pest, possibly because it causes the leaves to curl tightly, which protects the enclosed aphids (Burd et al.,1998). Although RWA prefers cereal crops (Butts \& Pakendorf, 1984), it also feeds on other cultivated and wild grasses (Kriel et al., 1984; Kindler \& Spomer, 1986).

The biology and ecology of both these aphid pests has been studied in the United States (Puterka et al., 1988, 1993; Shufran et al., 1991, 1997, 2000; Shufran \& Wilde, 1994; Kieckhefer et al., 1995; Ullah \& Peters, 1996). However, no information is available on the distribution or population biology of these aphids in South America. Important outbreaks of greenbug occurred in 1989, 1990 and 1995 in the centre of Argentina (Arriaga, pers. comm.). In 1998, outbreaks of RWA occurred in Buenos Aires and Córdoba provinces. No change in biotype composition occurred in the greenbug populations collected in the centre of Argentina (Córdoba and Santa Fe provinces) (Almaraz et al., 1990). However, considerable variation was found in their isoenzymes (Gimenez et al, 1991; Castro et al., 1996). The aphids collected from Córdoba and Santa Fe were subsequently analysed for $\mathrm{mt}$ (mitochondrial) DNA polymorphisms by Martínez et al., (1993) and Castro (1994). The values of their genetic distances (Nei, 1987) were similar to those found by Powers et al., (1989) for B and C biotypes in the USA. Nonetheless, mtDNA haplotypes of Argentinean and Spanish clones showed no relationship with biotype characterization (Martinez et al., 1993; Castro 1994), which accords with recent results published by Anstead et al. (2002). Since both aphid species are important pests of cereals and virus vectors (Fereres et al., 1993; Pérez et al., 1995), a better understanding of their biology is likely to facilitate their control.

The objectives of this paper were to: 1) study the distribution of the greenbug and RWA in Argentina and Chile; and 2) determine the variability, within and between populations, in biotype composition, the incidence of sexual reproduction and host preferences.

\footnotetext{
* Corresponding author.
} 


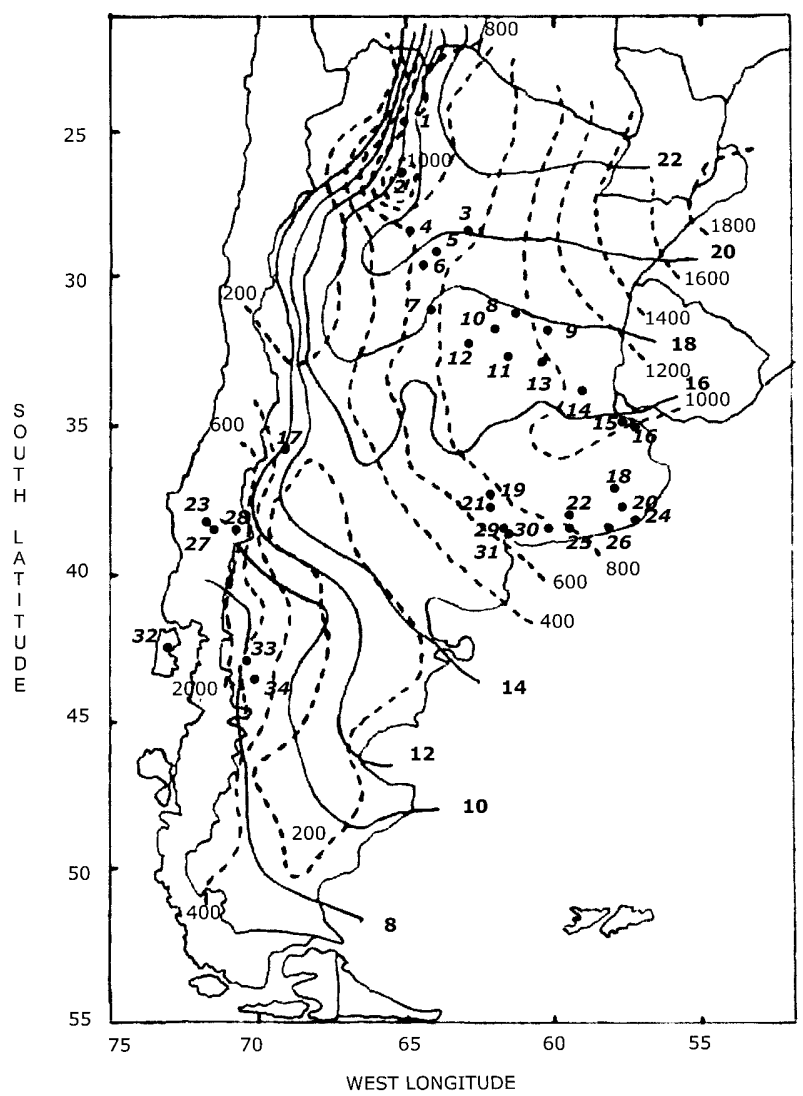

Fig. 1. Isohyets (------), isothermals $(-)$ and the geographical location of the collection site of Schizaphis graminum and Diuraphis noxia in Argentina and Chile.

\section{MATERIAL AND METHODS}

Aphids were collected from 34 localities in Argentina and southern Chile, including dry steppe (Fig. 1, locations 10, 12, 19, 21, 29, 31, 34), deserts (3 and 4), humid subtropical regions with warm summers $(1,2)$, localities with a moderate climate and all year rain fall $(8,9,11,13-16,18,20,22-26,30,32,33)$ and undifferentiated mountains $(5-7,17,27,28)$. The designation of the localities follows the classification used by Koppen (1923). Samples of varying numbers were collected from cereal crops and wild grasses every 50 to $100 \mathrm{~km}$ (Table 1), in autumn and spring, from 1996 to 1999.

Aphids were reared on susceptible wheat (cv. 'Buck Ombú') and barley (cv. 'Bordenave Ranquelina') plants growing in pots $(500 \mathrm{cc})$ covered with a plastic cage. Individuals from each population (i.e., collected on the same host and locality in each season) were allowed to reproduce parthenogenetically under controlled conditions $\left(20-22^{\circ} \mathrm{C}, 60-70 \%\right.$ relative humidity and $16 \mathrm{~h}$ photophase) and then 20 to 30 individuals from each population were used to establish single asexual lineages ("clones"). In most of the regions sampled, greenbug and RWA were found accompanied by Sitobion avenae (Fabricius), Rhopalosiphum padi (Linnaeus), R. maidis (Fitch) and Metopolophium dirhodum (Walker). There were twelve localities in which RWA was not found, but only one where greenbug was absent (Table 1 , locality 28 ).

Aphid clones were reared separately on different cultivars of cereals (following Porter et al., 1997) and the aphid biotype identified by its antibiotic responses (reproductive rate, mortality and duration of immature period, compared with that recorded for the same clone on a susceptible cultivar; Ramos et al., 1998, 2003) and the tolerance of the plants to the aphid (chlorotic damage, plant height and number of expanded leaves; Noriega et al., 1998, 2002).

The ability of aphids to produce sexuals was studied by subjecting them to natural conditions from $1^{\text {st }}$ March to $30^{\text {th }}$ November at La Plata $\left(34^{\circ} 55^{\prime} \mathrm{S}, 57^{\circ} 57^{\prime} \mathrm{W}\right)$ and recording every other day the presence of sexuals (males and oviparae) and eggs over a four year period, 1997-2001. Populations and clones derived there from were placed outdoors on susceptible plants growing in pots $(1000 \mathrm{cc})$ and covered with a plastic, transparent

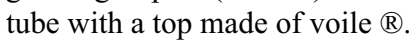

Aphid host preferences were studied by giving aphids a free choice of plants at the same growth stage (second leaf fully expanded) and each growing in a pot $(5 \mathrm{~cm}$ diameter $\times 10 \mathrm{~cm}$ high). Ten different host plants were randomly placed in a circle, with their leaves directed towards the centre of the circle. One hundred adult apterous aphids, equivalent to 10 aphids per plant, were placed in the lid of a Petri dish $(20 \mathrm{~cm}$ diameter), which was inverted over the leaves in the centre of the circle, following the methodology of J. Pettersson, (pers. comm.). In order to avoid the direction of light influencing plant selection, this assay was carried out in the dark. Each combination was replicated ten times. After $2 \mathrm{~h}$ and again after $24 \mathrm{~h}$, the number of adult aphids on each plant was recorded. Since both recordings were not significantly different $(P=0.05)$, only the results after $24 \mathrm{~h}$ are presented (Table 2). For a particular host, the average of the recordings after $24 \mathrm{~h}$ was used (Table 2). The cultivars tested were susceptible cultivars of wheat (Triticum aestivum L.) (cv. 'Buck Ombú'), barley (Hordeum vulgare L.) (cv. 'Bordenave Ranquelina'), rye (Secale cereale L.) (cv. 'Don Enrique'), oats (Avena sativa L.) (cv. 'Buck 152'), sorghum (Sorghum bicolor M.) (cv. 'NTK147'), triticale (Triticumsecale) (cv. 'Pampeano'), tritordeum (Triticum x Hordeum chilense M.) (cv. 'Cdb197-2'), bromus (Bromus catharticus L.) (cv. 'Miguel'), Hordeum murinum (L.) (cv. 'FA194'), Poa pratensis (L.) (cv. 'FA4796') and a selection of Sorghum halepensis (cv. 'FA1992/96').

Data were analysed by ANOVA, whilst the Duncan's Multiple Range Test was used to compare differences between clones, and the effect of host, region and time of the year when the aphids were collected (SAS, 1998).

\section{RESULTS AND DISCUSSION}

\section{Schizaphis graminum}

The distribution of the greenbug ranged from $24^{\circ} 40^{\prime}$ to $43^{\circ} 28^{\prime} \mathrm{S}$, bounded by isothermals $18-20^{\circ} \mathrm{C}$ and $8-10^{\circ} \mathrm{C}$ and isohyets $400-600 \mathrm{~mm}$ and $>1200 \mathrm{~mm}$ (Fig. 1).

This aphid was collected from many plant species (Table 1). At low latitudes it was found mainly on $S$. halepensis (localities 1, 2, 4 and 5).

Ten populations included known biotypes (Table 1). Samples from locality 16 included biotypes $\mathrm{B}, \mathrm{C}, \mathrm{E}$ and $\mathrm{F}$, whereas those from localities 15,18 and 30 consisted only of biotypes B and C in the ratios $1: 1,1.7: 1$ and $1: 2$, respectively. In twenty four of the populations the aphids could not be assigned to a biotype (Ramos et al., 1998, 2003).

There was no apparent correlation between the locality from which aphids were collected and the period required for the induction of sexuals. Most of the populations required an extended period for sexual induction, ranging from 120 days (localities 1 and 2) to 180 days (localities 10, 11, 15, 16, 18, 20, $21,23,29,31,32,33)$. The most precocious populations in this respect were those from localities 3 and 26 (36 days), 4 (42 d), 27 (43 d), 22 and 24 (54 d), 25 (63 d), 30 (67 d), and aphids from locality 34 did not produce sexuals. 
TABLE 1. The place, geographical location in Argentina and Chile (by latitude and longitude), aphid species, biotypes, number of individuals collected and host plant (wheat: T. aest.; barley: H. vulg.; oat: A.sat.; Hordeum spp: H. murinum, H. marinum, H. chilense; Sorghum: S. halepensis, S. bicolor and S. sacharata).

\begin{tabular}{|c|c|c|c|c|c|}
\hline \multirow[t]{2}{*}{ Populations } & \multicolumn{2}{|c|}{ GPS Data } & \multirow[t]{2}{*}{ Aphids } & \multirow[t]{2}{*}{ Biotype } & \multirow[t]{2}{*}{ Number of individuals on each host plant ${ }^{1}$} \\
\hline & South Lat. & West Long. & & & \\
\hline 1. Salta & $24^{\circ} 40^{\prime}$ & $65^{\circ} 03^{\prime}$ & S. graminum & & S. halepensis- 5 \\
\hline \multirow[t]{2}{*}{ 2. Tucumán } & $26^{\circ} 50^{\prime}$ & $65^{\circ} 12^{\prime}$ & S. graminum & & S. halepensis- 5 \\
\hline & & & D. noxia & & S. halepensis- 5 \\
\hline \multirow[t]{2}{*}{ 3. Ceres } & $28^{\circ} 36^{\prime}$ & $62^{\circ} 57^{\prime}$ & S. graminum & & Hordeum spp-1, S. halepensis-2 \\
\hline & & & D. noxia & & Bromus-2, S. halepensis-2 \\
\hline \multirow[t]{2}{*}{ 4. Frías } & $28^{\circ} 39^{\prime}$ & $65^{\circ} 09^{\prime}$ & S. graminum & & S. halepensis- 5 \\
\hline & & & D. noxia & & S. halepensis- 5 \\
\hline \multirow[t]{2}{*}{ 5. Cruz del Eje } & $29^{\circ} 10^{\prime}$ & $64^{\circ} 20^{\prime}$ & S. graminum & & S. halepensis- 5 \\
\hline & & & D. noxia & & S. halepensis-5 \\
\hline \multirow[t]{2}{*}{ 6. L.V. Mansilla } & $29^{\circ} 48^{\prime}$ & $64^{\circ} 43^{\prime}$ & S. graminum & & Bromus-2, Setaria-1 \\
\hline & & & D. noxia & & Bromus-1, Setaria-1 \\
\hline \multirow[t]{2}{*}{ 7. La Cumbre } & $30^{\circ} 59^{\prime}$ & $64^{\circ} 29^{\prime}$ & S. graminum & & Hordeum spp-5, Bromus-5 \\
\hline & & & D. noxia & & Hordeum spp-5, Bromus-5 \\
\hline 8. Rafaela & $31^{\circ} 10^{\prime}$ & $61^{\circ} 28^{\prime}$ & S. graminum & & Sorghum-5 \\
\hline 9. Paraná & $31^{\circ} 52^{\prime}$ & $60^{\circ} 29^{\prime}$ & S. graminum & & T. aest. -6, Sorghum-6, Bromus -6 \\
\hline 10. Córdoba Norte & $31^{\circ} 40^{\prime}$ & $62^{\circ} 20^{\prime}$ & S. graminum & & Sorghum-5, A. sat-5 \\
\hline \multirow[t]{2}{*}{ 11. Córdoba Sur } & $32^{\circ} 40^{\prime}$ & $61^{\circ} 53^{\prime}$ & S. graminum & & H. vulg. -5 , A. sat. -5 \\
\hline & & & D. noxia & & H. vulg. -5, A. sat. -5 \\
\hline 12. Va. María & $32^{\circ} 25^{\prime}$ & $63^{\circ} 15^{\prime}$ & S. graminum & & A. sat. -5 \\
\hline 13. Rosario & $32^{\circ} 57^{\prime}$ & $60^{\circ} 39^{\prime}$ & S. graminum & & T. aest. -6, H. vulg. -6, Bromus-5, Sorghum-5 \\
\hline 14. Baradero & $33^{\circ} 49^{\prime}$ & $59^{\circ} 30^{\prime}$ & S. graminum & & Sorghum-5, A. sat. -5 . \\
\hline 15. Los Hornos & $34^{\circ} 55^{\prime}$ & $57^{\circ} 57^{\prime}$ & S. graminum & $\mathrm{B}, \mathrm{C}$ & A. sat. -6, H. vulg. -6, Poa- 6 \\
\hline 16. B. Bavio & $35^{\circ} 05^{\prime}$ & $57^{\circ} 44^{\prime}$ & S. graminum & $\mathrm{B}, \mathrm{C}, \mathrm{E}, \mathrm{F}$ & A. sat. -6 , Sorghum-6, Hordeum spp. -6 \\
\hline \multirow[t]{2}{*}{ 17. Malargue } & $35^{\circ} 30^{\prime}$ & $69^{\circ} 35^{\prime}$ & S. graminum & & Rye-3, Bromus-5, Hordeum spp. -5 \\
\hline & & & D. noxia & & Rye-2, Bromus-5, Hordeum spp.-5 \\
\hline 18. Ayacucho & $37^{\circ} 08^{\prime}$ & $58^{\circ} 29^{\prime}$ & S. graminum & $\mathrm{B}, \mathrm{C}$ & Hordeum spp.-3, Poa-5. \\
\hline \multirow[t]{2}{*}{ 19. Puán } & $37^{\circ} 33^{\prime}$ & $62^{\circ} 46^{\prime}$ & S. graminum & $\mathrm{C}$ & T. aest. $-5, H$. vulg. -5 , Rye-5 \\
\hline & & & D. noxia & & T. aest. $-5, H$. vulg. -6 , Rye- 6 , Triticale- 5 \\
\hline \multirow[t]{2}{*}{ 20. Balcarce } & $37^{\circ} 50^{\prime}$ & $58^{\circ} 17^{\prime}$ & S. graminum & $\mathrm{C}$ & T. aest. -3, H. vulg. -3 , Triticale-3 \\
\hline & & & D. noxia & & T. aest. $-3, H$. vulg.-3, Triticale-3 \\
\hline \multirow[t]{2}{*}{ 21.Bordenave } & $37^{\circ} 51^{\prime}$ & $63^{\circ} 01^{\prime}$ & S. graminum & $\mathrm{B}, \mathrm{C}, \mathrm{F}$ & H. vulg. -5 , A. sat. -5 , Rye- 5 , Triticale-5 \\
\hline & & & D. noxia & & H. vulg. -5 , A. sat. -5 , Rye- 5 , Triticale- 5 \\
\hline \multirow[t]{2}{*}{ 22. G. Chavez } & $38^{\circ} 02^{\prime}$ & $60^{\circ} 05^{\prime}$ & S. graminum & & T. aest.-6, Bromus-6, A.sat.-6, H.vulg.-6, T. durum-6 \\
\hline & & & D. noxia & & T. aest.-6, Bromus-6, A.sat.-6, H. vulg.-6, T. durum-6 \\
\hline \multirow[t]{2}{*}{ 23. Osorno ${ }^{2}$} & $38^{\circ} 13^{\prime}$ & $72^{\circ} 20^{\prime}$ & S. graminum & & Rye-6, T.aest.-6 \\
\hline & & & D. noxia & & Rye-6, T.aest. -6 \\
\hline 24. Miramar & $38^{\circ} 15^{\prime}$ & $57^{\circ} 50^{\prime}$ & S. graminum & & T. aest. -5, H. vulg. -5, Bromus -5 \\
\hline 25. Tres Arroyos & $38^{\circ} 23^{\prime}$ & $60^{\circ} 17^{\prime}$ & S. graminum & & T. aest. $-6, T$. durum- $6, H$. vulg. -6 , Triticale- 6 \\
\hline & & & D. noxia & & T. aest. -6, T. durum- 6 , $H$. vulg. -6 , Triticale- 6 \\
\hline 26. La Dulce & $38^{\circ} 25^{\prime}$ & $58^{\circ} 42^{\prime}$ & S. graminum & $\mathrm{F}, \mathrm{C}$ & A. sat. $-6, H$. vulg. -6, T. aest. -6 \\
\hline & & & D. noxia & & A. sat.-6, H. vulg.-6, T. aest. -6, T. durum-6 \\
\hline 27.Temuco ${ }^{2}$ & $38^{\circ} 20^{\prime}$ & $72^{\circ} 20^{\prime}$ & S. graminum & & T. aest. -5, A. sat. -5 \\
\hline & & & D. noxia & & T. aest. -5, A. sat. -5 \\
\hline 28. Lonquimay ${ }^{2}$ & $38^{\circ} 26^{\prime}$ & $71^{\circ} 21^{\prime}$ & D. noxia & & A. sat.- 5 \\
\hline 29. Cabildo & $38^{\circ} 30^{\prime}$ & $61^{\circ} 54^{\prime}$ & S. graminum & $\mathrm{C}$ & T. aest. -5 , Tritordeo- 5 \\
\hline & & & D. noxia & & T. aest. -4 , Tritordeo- 5 \\
\hline 30. Copetonas & $38^{\circ} 30^{\prime}$ & $60^{\circ} 28^{\prime}$ & S. graminum & $\mathrm{B}, \mathrm{C}$ & T. aest. -5, H. vulg. -5 , A. sat. -5 \\
\hline & & & D. noxia & & T. aest. -5, H. vulg. -5, A. sat. -5 \\
\hline 31. Bahía Blanca & $38^{\circ} 44^{\prime}$ & $62^{\circ} 16^{\prime}$ & S. graminum & $\mathrm{C}$ & T. aest-5, T. durum-5 \\
\hline & & & D. noxia & & T. aest. $-5, T$. durum -5 \\
\hline 32. Castro $^{2}$ & $42^{\circ} 29^{\prime}$ & $73^{\circ} 45^{\prime}$ & S. graminum & & Dactylis spp. -5 \\
\hline 33. Esquel & $42^{\circ} 55^{\prime}$ & $71^{\circ} 20^{\prime}$ & S. graminum & & T. aest. -5 \\
\hline & & & D. noxia & & T. aest. -5 \\
\hline 34. Teka & $43^{\circ} 28^{\prime}$ & $70^{\circ} 50^{\prime}$ & S. graminum & & T. aest. -5, Bromus -5 \\
\hline & & & D. noxia & & T. aest. -5, Bromus -5 \\
\hline
\end{tabular}

1. Number of aphids collected: $1=10-19 ; 2=20 ; 3=21-49 ; 4=50 ; 5=50-100 ; 6=>100$

2. Chile 
TABLE 2. Number of adult aphids recorded on each of the hosts in the choice test after $24 \mathrm{~h}$ for greenbug (A) and RWA (B). Values in brackets are SEs. Values in a column with different letters are significantly different $(\mathrm{P}=0.05)$.

\begin{tabular}{|c|c|c|c|}
\hline \multicolumn{4}{|l|}{ A } \\
\hline \multirow[t]{2}{*}{ Test host } & \multirow[t]{2}{*}{$\mathrm{N}$} & \multicolumn{2}{|c|}{ Greenbug collected from } \\
\hline & & Cereals* & Grasses* \\
\hline Barley & 10 & $30.4^{\mathrm{a}}( \pm 4.25)$ & $12.54^{\mathrm{c}}( \pm 1.26)$ \\
\hline Wheat & 10 & $22.1^{\mathrm{b}}( \pm 3.20)$ & $9.23^{\mathrm{d}}( \pm 1.03)$ \\
\hline Oat & 10 & $10.2^{\mathrm{c}}( \pm 1.32)$ & $15.10^{\mathrm{b}}( \pm 1.14)$ \\
\hline Triticale & 10 & $10.3^{\mathrm{c}}( \pm 1.21)$ & $7.10^{\mathrm{d}}( \pm 1.17)$ \\
\hline Tritordeo & 10 & $10.0^{c}( \pm 1.18)$ & $8.09^{\mathrm{d}}( \pm 1.30)$ \\
\hline S. bicolor & 10 & $6.10^{\mathrm{d}}( \pm 0.64)$ & $24.23^{\mathrm{a}}( \pm 3.25)$ \\
\hline S. halepensis & 10 & $6.09^{\mathrm{d}}( \pm 0.62)$ & $22.12^{\mathrm{a}}( \pm 2.68)$ \\
\hline Rye & 10 & $4.17^{\mathrm{e}}( \pm 0.58)$ & $2.03^{\mathrm{e}}( \pm 0.34)$ \\
\hline \multicolumn{4}{|l|}{ B } \\
\hline \multirow[t]{2}{*}{ Test host } & $\mathrm{N}$ & \multicolumn{2}{|c|}{ Russian wheat aphid collected from } \\
\hline & & Cereals* & Grasses* \\
\hline Barley & 10 & $16.83^{\mathrm{ab}}( \pm 2.02)$ & $9.54^{\mathrm{a}}( \pm 2.30)$ \\
\hline Oat & 10 & $14.17^{\mathrm{b}}( \pm 1.56)$ & $15.46^{\mathrm{b}}( \pm 1.78)$ \\
\hline Wheat & & $11.21^{\mathrm{cd}}( \pm 1.27)$ & $9.47^{\mathrm{c}}( \pm 1.15)$ \\
\hline Tritordeo & 10 & $11.02^{\mathrm{cd}}( \pm 1.21)$ & $10.28^{c}( \pm 1.35)$ \\
\hline Triticale & 10 & $9.87^{\mathrm{de}}( \pm 1.08)$ & $8.77^{\mathrm{cd}}( \pm 1.03)$ \\
\hline Rye & 10 & $8.96^{\mathrm{ef}}( \pm 0.97)$ & $5.64^{\mathrm{g}}( \pm 0.67)$ \\
\hline Bromus spp. & 10 & $7.85^{\mathrm{fg}}( \pm 0.84)$ & $7.15^{f}( \pm 0.82)$ \\
\hline Poa spp. & 10 & $7.02^{g}( \pm 0.87)$ & $7.38^{\mathrm{ef}}( \pm 0.88)$ \\
\hline Hordeum spp. & 10 & $6.84^{\mathrm{g}}( \pm 0.86)$ & $8.13^{\text {de }}( \pm 0.82)$ \\
\hline S. halepensis & 10 & $6.29^{\mathrm{g}}( \pm 0.74)$ & $9.68^{\mathrm{c}}( \pm 1.04)$ \\
\hline
\end{tabular}

*The host from which the aphids were collected in the field.

Seven populations and their derived clones did not produce eggs, either because only male individuals were produced (localities 6, 7, and 10) or only sexual females (5 and 17). Moreover, only one sex, either male or oviparae, was recorded for clones collected from localities 3 and 4 . From the samples collected at locality 3 , six clones produced males, six oviparae and eight produced only parthenogenetic individuals. From the samples collected from locality 4, eight clones produced females, four males and nine only parthenogenetic individuals. In the populations from localities 3 and 4, aphids produced both sexes, but not simultaneously, and consequently did not mate.

For ten of the populations studied, every clone produced sexuals and eggs $(1,2,8,9,14,20,23,24,26$ and 32). For eight localities $(16,18,19,25,28-31), 50-90 \%$ of the twenty clones produced sexuals and eggs. The aphids from locality 12 produced eggs, but none of the twenty clones derived from this population produced eggs. Eight of the clones only produced oviparae, four only males and the rest only parthenogenetic individuals. None of the clones produced both sexes. Of the ten clones from locality 11 , seven produced sexuals, but only four of these produced eggs as three produced only females. Similar results were obtained for the aphids collected at locality 13 (of over fifteen clones, three produced both sexes, two produced only males, and the rest were obligately parthenogenetic), 15 (all twenty clones produced sexuals but only half produced both sexes), 21 and 33 (90\% of twenty clones produced sexuals and $80 \%$ eggs), 22 (60\% of 20 clones produced sexuals and only
$20 \%$ eggs) and 27 (60\% of 20 clones produced sexuals and $30 \%$ eggs).

Whether clones produce sexual forms is under genetic control and subject to environmental modulation, as in other cereal aphid species; however, clones producing only sexual females are not recorded (Simon et al., 1997; Rispe et al., 1999). In those populations composed of clones that produced both sexes and others that produced only females, sexual reproduction occurred, but in the populations from localities 6,7 and 10 , which did not produce sexual females, only parthenogenetic reproduction occurred.

The production of sexuals by greenbugs occurred at day lengths shorter than $9 \mathrm{~h}$ (mean $\left.8.00 \mathrm{~h} \pm 40^{\prime}\right)(P \geq 0.01)$. For those clones that required 32-70 days before producing sexuals (clones from populations 3, 4, 22, 24, 25, 26 and 27) this was independent of temperature, as day/night temperatures from March to June ranged from $25-17^{\circ} \mathrm{C} / 20-12^{\circ} \mathrm{C}$ in La Plata. Moreover, several of these clones produced sexuals under controlled conditions at a constant temperature $\left(20 \pm 2^{\circ} \mathrm{C}\right)$ in an insectary (Noriega et al., 2000). Aphids collected at lower latitudes (localities 1,2 ) required a shorter day length for sexual production (they started producing sexuals in July when the photoperiod was 9L : 16D, $120 \pm 3$ days from $1^{\text {st }}$ March) than those collected at higher latitudes (160-180 days to elapse before producing sexuals: populations $10,11,15-18,20,21,23$, $29,31,32,33)$, since they produced sexuals from $1^{\text {st }}$ August to $20^{\text {th }}$ August when day-length is $10 \mathrm{~h}$ to $10 \mathrm{~h} 30^{\prime}$. Greenbugs collected from grasses at lower latitudes (localities 3, 4, 5, 6) did not differ from those from cereals in the induction period required for sexual production (70.6 \pm 6 days $v s 68.4 \pm 7.2$ days, respectively, $P \geq 0.05$ ). However, aphids collected from grasses at higher latitudes, locality 34 , did not produce sexuals.

Greenbugs collected from wheat and barley preferred these hosts to oats, rye, triticale and tritordeum in free choice tests (Table 2A), whilst those collected from oats showed a significantly lower preference for wheat and barley. Lastly, aphids from grasses preferred sorghums and oats. This host preference may indicate that $S$. graminum is better adapted to sorghums and oats than to wheat and barley. Sorghums include Sorghum halepensis, an aggressive weed that can be found in the field throughout the year in regions with warm winters. It may host aphids that could infest cultivated cereals and possibly transmit virus to other economically important crops of the region, although this has yet to be proven.

\section{Diuraphis noxia}

RWA was found between $26^{\circ} 50^{\prime} \mathrm{S}$ to $43^{\circ} 28^{\prime} \mathrm{S}$ (Table 1), bounded by isothermals $20-22^{\circ} \mathrm{C}$ and $8-10^{\circ} \mathrm{C}$ and isohyets $400-600 \mathrm{~mm}$ and $2000 \mathrm{~mm}$ (Fig. 1). In Chile, this species was only found in Osorno county, which lies on the isothermal $8-10^{\circ} \mathrm{C}$, bounded by isohyets $2000 \mathrm{~mm}$ and $1000 \mathrm{~mm}$, on crops at an advanced stage of growth in late spring. It was uncommon in the Central Valley and close to the Pacific Ocean, yet abundant above an altitude of $1000 \mathrm{~m}$, where the rainfall is greater than at sea level (Prado, pers. comm.). Ortego \& Delfino (1994) report that RWA is found up to an altitude of $1800 \mathrm{~m}$ in Chile. Two localities (27 and 28) where RWA was collected in Chile are at 1000 and $2400 \mathrm{~m}$ above sea level, respectively, and locality 23 is in the Central Valley. In Argentina, populations were collected at localities $2,5-7,17$ and 33 , which are at different altitudes ranging from 400 to $1200 \mathrm{~m}$.

RWA from locality $34\left(43^{\circ} 28^{\prime} \mathrm{S}\right)$ was the most southerly population reported, and that found at locality $2\left(26^{\circ} 50^{\prime} \mathrm{S}\right)$, the most northerly in all of South America (Table 1). The aphid was found in regions with $2000 \mathrm{~mm}$ of rainfall (localities 2, 27, 28, 33 ), which contrasts with the findings in the USA. In the 
Northern Hemisphere, this species occurs in areas bounded by the isohyets 750 and $1000 \mathrm{~mm}$. On both subcontinents, however, its distribution follows the isotherm $5-10{ }^{\circ} \mathrm{C}$.

In the field RWA colonises a great range of hosts, e.g. rye, barley, triticale and grasses such as Poa, Bromus and Hordeum spp., and in South America even oats, not previously reported as a host (Table 1). At low latitudes, RWA was found infesting $S$. halepensis, and at high latitudes, samples were collected in spring and autumn from cultivated and/or wild grasses.

Only a few of the RWA clones $(20 \%)$ produced sexuals irrespective of host, the period of year, or region from which they were collected (localities 11, 17, 20, 23, 28, 31). Bellone et al. (1999) report that the low production of sexuals by RWA is independent of the conditions under which they are reared $(12 \%$ of clones reared under $9.0 \mathrm{~h}$ light and $12^{\circ} \mathrm{C}$ versus $14 \%$ of those reared under $9.0 \mathrm{~h}$ light and $20^{\circ} \mathrm{C}$ ). Probably the temperature and extreme short day conditions prevailing at La Plata (34 $55^{\circ}$ S) are unsuitable for the induction of sexuals, whereas in the field at Mendoza $\left(35^{\circ} 30^{\prime} \mathrm{S}\right)$, this species produces sexuals (Ortego, pers. comm.).

RWA collected from cereals and other grasses showed a preference for cereals in the free choice tests (Table 2B), but those collected from $S$. halepensis equally preferred this host, wheat, tritordeum and triticale, as previously reported by Castro et al. (2000). This suggests that $S$. halepensis could be an alternative host to cereals for this aphid.

\section{Genetic structure}

Variability in restriction fragment length polymorphisms (RFLPs) of greenbug mtDNA (Martinez et al., 1993; Castro, 1994) and isoenzymes (Giménez et al., 1991; Castro et al., 1996) can be attributed to the long period of colonisation and the existence of sexual reproduction in the region from $24^{\circ} 40^{\prime}$ to $42^{\circ} 55^{\prime} \mathrm{S}$, and between $57^{\circ} 44^{\prime}$ and $73^{\circ} 45^{\prime} \mathrm{W}$. One would expect greenbug populations in Argentina and Chile to have a different genetic structure compared to those from the USA, because of the very different and contrasting climates of the two regions.

RWA showed variability in certain traits. This accords with high intra- and interpopulation variability in isoenzymes and allozymes reported by Castro et al. (1997). Such variability may be a consequence of the diverse environments in which both completely parthenogenetic and sexual clones coexist, living on a variety of hosts. Nonetheless, this pest was only recently introduced into the region.

\section{CONCLUSIONS}

The present results increase our understanding of the population biology of these two pest aphids in Argentina and Chile, information that may facilitate their control. In greenbug, sexual reproduction is wide-spread throughout Argentina and Chile, and whilst it appears widespread in RWA, only $20 \%$ of the clones tested actually produced sexuals. Thus there is the potential for more economically damaging clones to be produced by sexual reproduction. Yet so, further research is required on the relation between host preference, reproductive behaviour and the spatial and temporal distributions of both pest-aphid species in Argentina and Chile.

ACKNOWLEDGEMENTS. The authors acknowledge with gratitude the technical assistance of María Silvia Tacaliti, Marcelo Muñoz, Paula Mendy, Andrea Paglione and Andrea Kahan.

\section{REFERENCES}

Almaraz L.B, Arriaga H.O. \& Chidichimo H.O. 1990: Biotype composition of greenbug in Argentina. Annual Plant Resistance to Insect Newsletters 16: 71

Anstead J.A., Burd J.B. \& Shufran K.A. 2002: Mitochondrial DNA sequence divergence among Schizaphis graminum (Hemiptera: Aphididae) clones from cultivated and noncultivated hosts: haplotypes and host associations. Bull. Entomol. Res. 92: 17-24.

Bellone B. \& Almaraz L.B. 1995: The Russian Wheat Aphid: a new cereal pest in cereals in Argentina. Proc. III Latin Am. Congr. Entomol. Santiago, Chile, pp. 18-19.

Bellone B.B., Almaraz L.B. \& CAstro A.M. 1999: Evaluation of RWA (Diuraphis noxia) reproductive behaviour in populations collected in Chile and Argentina. Proc. VII Chilean Congr. Entomol. Arica, Chile, p. 180.

Burd J.D., Butts R.A., Elliot N.C. \& Shufran K.A. 1998: Seasonal development, overwintering biology, and host plant interactions of Russian wheat aphid (Homoptera: Aphididae) in North America. In: Quisenberry S.S. \& Peairs F.B. (eds): Response Model for an Introduced Pest - the Russian Wheat Aphid. Thomas Say Publ. Entomol. Entomol. Soc. of Am., Lanham, MD, USA, pp. 65-69.

ButTs P.A. \& PAKENDORF K.W. 1984: Wheat breeding for resistance to Diuraphis noxia, methodology and progress. In: Walters M.C. (ed.): Progress in Russian Wheat Aphid (Diuraphis noxia, Mordv.). Research in the Republic of South Africa. Repub. S. Africa, Dept. Agric. Tech. Communication 191, pp. 47-52.

CAstro A.M. 1994: Characterization of greenbug population and clones from Argentina. In: The Importance of Hordeum chilense for Breeding Aphid Resistance in Cereals. PhD. Thesis, 165 pp., University of Córdoba, Spain, pp. 98-128.

Castro A.M., Ramos S., Frangi P., Giménez D., Vasicek A., \& MuÑoz M. 1996: Variability determined by isoenzymes between and within Schizaphis graminum (Rondani) populations. Proc. IV Chilean Congr. Entomol. Temuco, Chile, 132 pp.

Castro A.M., Clúa A., Giménez D.O., Ramos S. \& Vasicek A. 1997: Evaluation of genetic variability in aphid traits of ecological importance in populations of Schizaphis graminum and Diuraphis noxia collected in Argentina and Chile. Proc. XXVIII Argentinean Congr. Genetics. Tucumán, Argentina, p. 118.

Castro A.M., Clúa A.A., Bellone B., Almaráz L.B., Giménez D.O. \& Chidichimo H.O. 2000: Ecological studies of Russian wheat aphid in Argentina and Chile. Proc. XXI Int. Congr. Entomol. Iguazú, Brasil, p. 233.

Castro A.M., Ramos S.B., Vasicek A., Worland A.J., Giménez D.O., Clúa A.A. \& SuArez E. 2001: Identification of wheat chromosomes involved with different types of resistance against greenbug (Schizaphis graminum, Rondani) and the Russian wheat aphid (Diuraphis noxia, Mordvilko). Euphytica 118: $321-330$.

Fereres A., Pérez P., Gemeno C. \& Ponz F. 1993: Transmisión of Spanish Pepper-PVY isolates by aphid vectors: epidemiological implications. Env. Entomol. 22: 1260-1265.

Giménez D.O., Brocchi G.N., Castro A.M., Almaraz L.B. \& Arriaga H.O. 1991: Greenbug variability evaluated by isozymes polymorphisms. Annual Plant Resistance to Insects Newsletter 17: 68-69.

Kieckhefer R.W., Gellner J.L., \& Riedell W.E. 1995: Evaluation of the aphid-day standard as a predictor of yield loss caused by cereal aphids. Agron. J. 87: 785-788 
KindLER S. D. \& SPRINGER T.L. 1989: Alternate hosts of Russian Wheat Aphid (Homoptera: Aphididae). J. Econ. Entomol. 82: $1358-1362$

KindLER S.D. \& SpOMER S.D. 1986: Biotypic status of six greenbug (Homoptera: Aphididae) isolates. Env. Entomol. 80: 394-397.

Koppen W. 1923: Die Klimate der Erde. Grundriss der Klimakunde. De Gruyter, Leipzig, Germany, $280 \mathrm{pp}$.

Kriel C.F., Hewitt P.H., De Jager J., Walters M.C., Fouche A. \& VAN DER Westhuizen M.C. 1984: Aspects of the ecology of the Russian Wheat Aphid, Diuraphis noxia, in the Bloemfontein district. II. Population dynamics. In: Walters M.C. (ed.): Progress in Russian Wheat Aphid (Diuraphis noxia, Mordv.). Research in the Republic of South Africa. Dept. Agric. Tech. Communication 191, pp. 14-21.

Martínez D., Latorre A. \& Castro A.M. 1993: Greenbug aggressiveness variability within and between biotypes by mtDNA. Proc. XVII Int. Congr. Genetics, Birmingham, England, p. 155.

NeI M. 1987. Molecular Evolutionary Genetics. Columbia University Press, New York, 420 pp.

Noriega A., Chidichimo H. \& Castro A.M. 1998: Biotype composition of several populations of greenbug. Proc. IV Wheat National Meeting. Mar del Plata, Argentina, pp. 31-32

Noriega A., Castro A.M., Clúa A.A. \& Chidichimo H.O. 2000: Artificial induction of sexuals in greenbug Proc. XXI Int. Congr. Entomol. Iguazú, Brasil, p. 848

Noriega A., Chidichimo H. \& Castro A.M. 2002: RWA and greenbug collected from humid regions: their reproductive behaviour under controlled conditions. Rev. Fac. Agron. La Plata 104: 85-92.

Ortego J. \& Delfino M.A. 1994: Diuraphis noxia (Mordvilko) (Homoptera: Aphididae) in Argentina. Rev. Fac. Agron. La Plata 70: 51-55.

Peairs F.V., Brooks L., Hein G., Johnson G., Massey B., Mc Bride D., Morrison W.P., Schultz J.T. \& Spackman E. 1989: Economic impact of the Russian wheat aphid in the western United States: 1987-88. Great Plain Agric. Council Publ. $\mathrm{N}^{\circ}$ 129, $23 \mathrm{pp}$

Perez P., Collar J.L., Avila C., Duque M. \& Fereres A. 1995: Estimation of vector propensity of potato virus $\mathrm{Y}$ in openfield pepper crops of Central Spain. J. Econ. Entomol. 88: 986-991.

Porter D.R., Burd J.D., Sufran K.A., Webster J.A. \& Teetes G.L. 1997: Greenbug (Homoptera: Aphididae) biotypes: selected by resistant cultivars or preadapted opportunists? $J$. Econ. Entomol. 90: 1055-1065.
Powers T.O., Jensen S.G., Kindler S.D., Stryker C.J. \& SANDALl L.J. 1989: Mitochondrial DNA divergence among greenbug (Homoptera: Aphididae) biotypes. Ann. Entomol. Soc. Am. 82: 298-302.

Puterka G.J., Peters D.C., Kerns D.L., Slosser J.E., Bush L., Worrall D.W. \& McNew R.W. 1988. Designation of two new greenbug (Homoptera: Aphididae) biotypes G and H. $J$. Econ. Entomol. 81: 1754-1759.

Puterka G.J., Black W.C., Steiner W.M. \& Burton R.L. 1993. Genetic variation and phylogenetic relationships among worldwide collections of the Russian wheat aphid, Diuraphis noxia (Mordvilko), inferred from allozyme and RAPD-PCR markers. Heredity 70: 604-618.

Ramos S., Chidichimo H.O. \& Castro A.M. 1998: Evaluation of antibiosis to isolates of greenbug (Schizaphis graminum, Rond.) in differential cultivars. Proc. XIX S. Amer. Congr. Entomol. Rio de Janeiro, Brasil, p. 300.

Ramos S., Castro A.M. \& Chidichimo H.O. 2003: Evaluation of damage in an oat cultivar produced by greenbug (Schizaphis graminum) populations collected in Argentina. Agrociencia 119: $57-69$.

Rispe C., Bonhomme J. \& Simon J.C. 1999: Extreme life-cycle and sex ratio variation among sexually produced clones of the aphid Rhopalosiphum padi (Homoptera: Aphididae). Oikos 86: $254-264$.

SAS 1998: SAS/STAT guide for personal computers, Carry NC.

Shufran K., Black IV W. \& Margolies D. 1991: DNA fingerprinting to study spatial and temporal distributions of an aphid, Schizaphis graminum (Homoptera: Aphididae). Bull. Entomol. Res. 81: 303-313.

Shufran K. \& WiLde G. 1994: Clonal diversity in overwintering populations of Schizaphis graminum (Homoptera: Aphididae). Bull. Entomol. Res. 84: 105-114.

Shufran K.A., Peters D.C. \& Webster J.A. 1997: Generation of clonal diversity by sexual reproduction in the greenbug, Schizaphis graminum. Insect Molec. Biol. 6: 203-209.

Shufran K.A., Burd J. D., Anstead A. \& Lushai G. 2000: Mitochondrial DNA sequence divergence among greenbug (Homoptera: Aphididae) biotypes: evidence for host-adapted races. Insect Molec. Biol. 9: 179-184.

Simon J.P., Martinez D. \& LatorRe A. 1997: Genetic variability in reproductive behaviour in Rhopalosiphum padi. Molec. Biol. 22: 1182-1190.

Ullah F. \& Peters D.C. 1996. Sexual capability of greenbugs (Homoptera: Aphididae). J. Kansas Entomol. Soc. 69: 153-159.

Received May 27, 2003; revised November 18, 2003; accepted November 25, 2003 